\title{
LYME BORRELIOSIS IN THE LUBLIN PROVINCE DURING THE COVID-19 PANDEMIC
}

\section{BORELIOZA Z LYME W WOJEWÓDZTWIE LUBELSKIM W CZASIE PANDEMII COVID-19}

\author{
Anna Pańczuk ${ }^{1(A, B, C, D, E, F)}$ \\ ${ }^{1}$ Faculty of Health Sciences, Pope John Paul II State School of Higher Education in Biała Podlaska, Poland
}

\author{
Authors' contribution \\ Wkład autorów: \\ A. Study design/planning \\ zaplanowanie badań \\ B. Data collection/entry \\ zebranie danych \\ C. Data analysis/statistics \\ dane - analiza i statystyki \\ D. Data interpretation \\ interpretacja danych \\ E. Preparation of manuscript \\ przygotowanie artykułu \\ F. Literature analysis/search \\ wyszukiwanie i analiza literatury \\ G. Funds collection \\ zebranie funduszy
}

Tables: 1

Figures: 3

References: 18

Submitted: 2021 Aug 26

Accepted: 2021 Sep 28

\section{Summary}

Background. Lyme borreliosis is the most common tick-borne disease in Poland. The onset of tick exposure in early spring 2020 coincided with the start of the COVID-19 pandemic. The aim of the study was to analyze the incidence of Lyme borreliosis in the Lublin Province and in individual counties of the area in the year preceding the start of the COVID-19 pandemic in Poland and in the first year of its duration (2019-2020). Material and methods. Epidemiological analysis was performed on the basis of data from the National Institute of Public Health - National Research Institute and data from the Regional SanitaryEpidemiological Station in Lublin. Results. In 2020, the incidence rate of Lyme borreliosis in the Lublin Province was registered to decrease more than 2 times compared to 2019 (from $87.4 / 100,000$ to $37.4 / 100,000$ ). Decreases in the number of recorded cases were observed in all quarters of 2020. The largest, more than 5 -fold decrease in the number of recorded cases was seen in Q4 (523 cases in 2019, 101 cases in 2020). The largest numerical decrease of the incidence rate was registered in Włodawa County $(-158.12 / 100,000)$, Biała Podlaska County (-143.43), Kraśnik County $(-122.20)$ and the city of Biała Podlaska $(-83.92)$. On the other hand, the largest percentage decrease of the rate was noted in Lublin County $(-92 \%)$, Biała Podlaska County (-91\%), Ryki County $(-90 \%)$ and the city of Biała Podlaska (-89\%). Conclusions. Significant decreases in the incidence of Lyme borreliosis observed in 2020 in the Lublin Province are undoubtedly related to the COVID-19 pandemic and difficulties in accessing medical care for patients with ailments other than those resulting from SARS-CoV-2 infection. Local healthcare providers should be alert to the possibility that more patients than ever before are presenting with a diagnosis of Lyme borreliosis delayed by the COVID-19 pandemic and, therefore, late manifestations of the disease.

Keywords: tick-borne diseases, Lyme borreliosis, pandemic, COVID-19, Poland

\section{Streszczenie}

Wprowadzenie. Borelioza z Lyme jest najbardziej rozpowszechnioną chorobą odkleszczową w Polsce. Poczatek ekspozycji na kleszcze wczesną wiosną 2020 roku zbiegł się z początkiem pandemii COVID-19. Celem pracy była analiza zachorowalności na boreliozę z Lyme w województwie lubelskim oraz w poszczególnych powiatach tego województwa w roku poprzedzajacym rozpoczęcie pandemii COVID-19 w Polsce oraz w pierwszym roku jej trwania (lata 2019-2020). Materiał i metody. Analizę epidemiologiczną przeprowadzono na podstawie danych Narodowego Instytutu Zdrowia Publicznego PZH - Państwowego Instytutu Badawczego oraz danych Wojewódzkiej Stacji Sanitarno-Epidemiologicznej w Lublinie. Wyniki. W roku 2020 w województwie lubelskim zarejestrowano ponad 2-krotny spadek wskaźnika zapadalności na boreliozę z Lyme w porównaniu z rokiem 2019 (z 87,4/100.000 do 37,4/100.000). Zmniejszenie liczby rejestrowanych zachorowań obserwowano we wszystkich kwartałach roku 2020. Największy, ponad 5-krotny spadek liczby rejestrowanych zachorowań zanotowano w kwartale IV (523 przypadki w 2019 roku, 101 przypadków w roku 2020). Największe liczbowe spadki wskaźnika zapadalności zarejestrowano w powiatach: włodawskim $(-158,12 / 100.000)$, bialskim $(-143,43)$, kraśnickim $(-122,20)$ oraz mieście Biała Podlaska $(-83,92)$. Z kolei najwiekksze procentowe spadki tego wskaźnika zanotowano w powiatach: lubelskim (-92\%), bialskim (-91\%), ryckim $(-90 \%)$ oraz mieście Biała Podlaska $(-89 \%)$. Wnioski. Obserwowane w 2020 roku w województwie lubelskim znaczne spadki wskaźnika zapadalności na boreliozę z Lyme niewątpliwie związane są z zaistniałą pandemią COVID-19 i trudnościami z dostępem do opieki medycznej pacjentów z innymi dolegliwościami niż wynikające z zakażenia SARS-CoV-2. Lokalny personel medyczny powinien być wyczulony na możliwość zgłaszania się większej niż dotychczas liczby pacjentów z odroczoną z powodu pandemii COVID-19 diagnozą boreliozy z Lyme i co z tym się wiąże późnymi objawami tej choroby.

Słowa kluczowe: choroby odkleszczowe, borelioza z Lyme, pandemia, COVID-19, Polska

Pańczuk A. Lyme borreliosis in the Lublin Province during the COVID-19 pandemic. Health Prob Civil. 2021; $15(4): 291-297$. 


\section{Introduction}

Lyme borreliosis is a bacterial infectious disease whose etiological agent, the spirochete Borrelia burgdorferi (at present Borreliella burgdorferi [1,2]), is transmitted to humans by ticks of the genus Ixodes. The disease is characterized by a complex pathogenesis and diverse course, and the clinical picture is associated with involvement of the skin, joints, nervous system, and heart [3].

Lyme borreliosis is the most common tick-borne disease in the temperate climate of the northern hemisphere [4], and in many European countries, including Poland, an increase in the incidence of the disease has been observed [3,4]. In Poland, B. burgdorferi infection can occur throughout the country, both in forest areas and in urban parks, so according to European Centre for Disease Prevention and Control (ECDC) recommendations, the whole country should be considered endemic. The highest incidence of Lyme borreliosis in Poland occurs in the north-eastern region, but this tendency gradually recedes in favor of the eastern and southern regions of the country [5].

In Poland, epidemiological surveillance for Lyme borreliosis was implemented in 1996. Until 2004, reports were made on the basis of a medical diagnosis. In a great many cases, it was based on non-specific clinical symptoms, most often confirmed by a positive screening test. To more accurately monitor the incidence of Lyme borreliosis, a case definition developed for routine epidemiologic surveillance was implemented in early 2005. This definition takes into account the results of the analysis of information from epidemiological investigations and the case definition adopted by the Centers for Disease Control and Prevention (CDC) in the USA and the European Union Controlled Action on Lyme Borreliosis (EUCALB) [6]. The definitions of incidence of infectious diseases used are aimed at standardizing reporting and ensuring comparability of data collected under epidemiological surveillance in Poland and in the European Community. The application of these definitions mainly concerns the classification and registration of cases by sanitary-epidemiological stations and the preparation of official reports by these institutions [7].

The analysis of the number of registered cases of Lyme borreliosis in Poland shows a clear increase of the incidence. Between 2005 and 2019, the incidence increased from 4,409 cases to 20,630. The incidence rate increased nearly 5-fold during this period from 11.5 to 53.7/100,000 residents. A detailed analysis of the incidence rate by year shows a steady increase through 2016 and stabilization in subsequent years through 2019 (Figure 1). According to preliminary data published by the National Institute of Public Health - National Research Institute (as of $22^{\text {nd }}$ July 2021), a significant decrease in the registered incidence of Lyme borreliosis in Poland was noted in 2020. The reported incidence was only 12,933 cases (incidence: 33.7/100,000) [8].

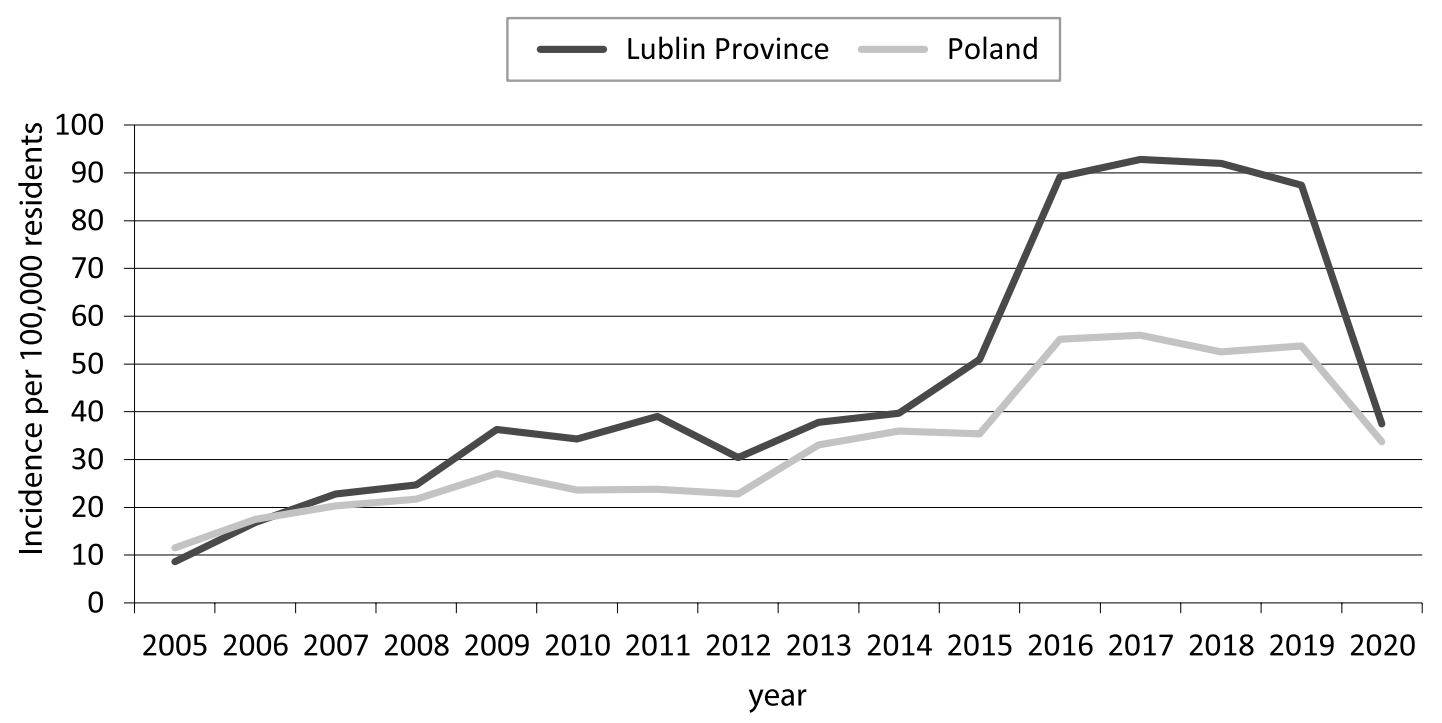

Figure 1. Incidence of Lyme borreliosis in Poland and in the Lublin Province in the years 2005-2020 (per 100,000 residents) Notes: Own elaboration based on data from the National Institute of Public Health - National Research Institute [8].

The Lublin Province is characterized by higher incidence rates of Lyme borreliosis than Poland as a whole. This situation has persisted since 2007. However, a very marked increase in the incidence rate, compared to the national rate, has occurred since 2016, when the regional rate was $89.2 / 100,000$, while the national rate was $55.2 / 100,000$. This variation continued in subsequent years (2017-2019), during which regional incidence rates were nearly 2 times higher than nationwide rates. In 2020, a marked decline in this indicator is registered. An 
analogous situation was found in Poland as a whole, however, in the Lublin Province the observed decrease was significantly greater. According to the data of the Regional Sanitary and Epidemiological Station in Lublin, only 784 cases of Lyme borreliosis were reported in 2020 (incidence: 37.4/100,000), while the year before more than twice as many: 1,843 cases (incidence: $87.4 / 100,000$ ) [9].

The onset of tick exposure in early spring 2020 coincided with the onset of the COVID-19 pandemic in Poland. The observed decreases in the number of reported cases of Lyme borreliosis in 2020 are so significant that it is difficult not to link them to the pandemic. In the Lublin Province, the first case of COVID-19 was detected in March 2020 in the Lublin County, and like other cases in Poland at that time, it occurred in a person who had contact with people coming to Poland from abroad (in this case from Italy). In 2020, 67,748 SARS CoV-2 cases were registered in the Lublin Province, including 30 possible, 17 probable, and 67,701 confirmed according to the COVID-19 case definition for epidemiological surveillance. COVID-19 incidence (probable and confirmed cases) was 3,212.01/100,000 residents, comparable to the nationwide incidence of 3,271.01/100,000. The highest incidence rate per 100,000 residents was noted in Biała Podlaska city $(4,637.04)$, Świdnik County $(4,535.07)$ and Lublin city $(4,312.44)$, while the lowest in Biłgoraj County $(1,948.09)$ [10].

The aim of the study was to analyze the incidence of Lyme borreliosis in the Lublin Province and in individual counties of the area in the year preceding the start of the COVID-19 pandemic in Poland and in the first year of its duration (2019-2020).

\section{Material and methods}

Epidemiological analysis was based on data from the National Institute of Public Health - National Research Institute (data on quarterly incidence of Lyme borreliosis in the Lublin Province in 2019 and 2020) and data from the Regional Sanitary and Epidemiological Station in Lublin (data on the number of registered cases of Lyme borreliosis and incidence rates in individual counties of the Lublin Province in 2019-2020).

\section{Results}

Quarterly comparison of the number of registered cases of Lyme borreliosis in 2019 and 2020 shows that a decrease in the number of registered cases of Lyme borreliosis in the Lublin Province was observed in all the quarters of 2020. The largest, more than 5-fold decrease from 523 cases in 2019 to 101 cases in 2020, was seen in Q4 (Figure 2).

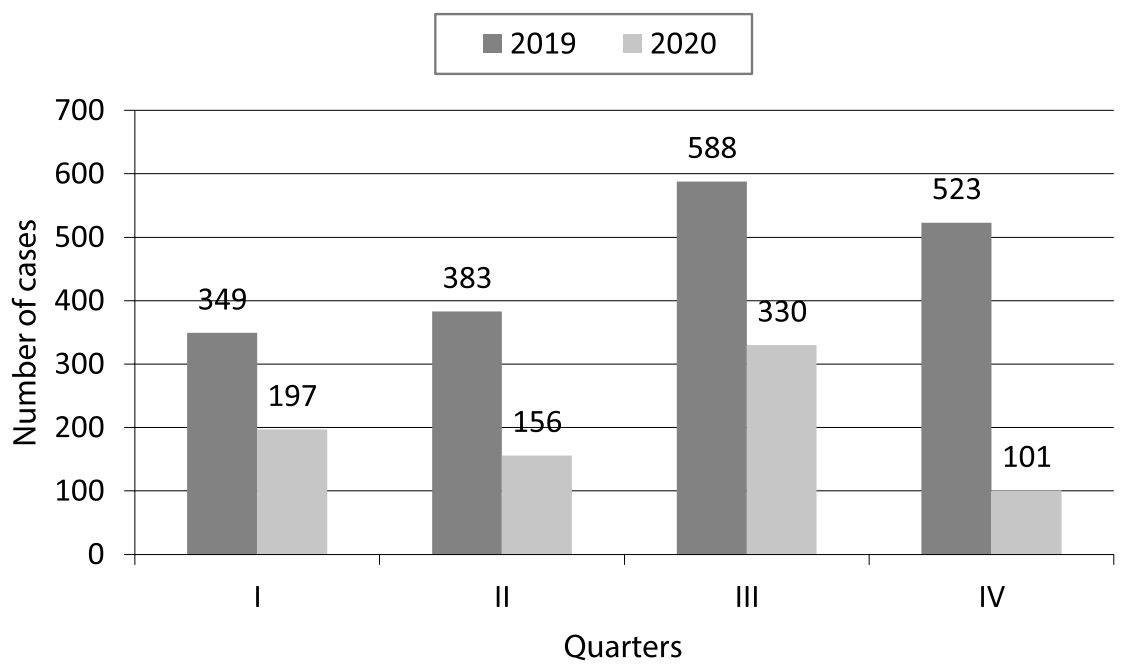

Figure 2. Number of cases of Lyme borreliosis in the Lublin Province by quarter in 2019 and 2020

Notes: Own elaboration based on data from the National Institute of Public Health - National Research Institute [8].

The percentage of incidence for each quarter in 2019 was as follows: Q1 - 18.9\%, Q2 - 20.8\%, Q3 - 31.9\%, Q4 - 28.4\%. In the following 2020, the quarterly breakdown changed significantly: Q1 - 25.1\%, Q2 - 19.9\%, Q3 - 42.1\%, Q4 - 12.9\%. There is a noticeable shift in the number of cases from Q4 to Q3 and Q1 (a 15.5 percentage point decrease in Q4 and a 10.2 increase in Q3 and Q2 by 6.2 percentage points).

In 2019, among all counties in the Lublin Province, the highest incidence rate of Lyme borreliosis was found in Włodawa County $(255.52 / 100,000)$. This rate was almost 3 times higher than the rate for the whole Province 
(87.4) and more than 4 times higher than the national rate (53.7). Other counties with high incidence rates were Kraśnik County (181.44), Janów Lubelski County (161.90), Biała Podlaska city (157.98), Krasnystaw County (156.50), Chełm County (155.10), and Tomaszów Lubelski County (153.45). The lowest incidence rates of Lyme borreliosis were found in Lublin city, Łęczna County, Lubartów County, Lublin County, Łuków County and Ryki County. In these counties the incidence rate was more than 2 times lower than the regional rate.

In 2020, the highest Lyme borreliosis incidence rates were found in Janów Lubelski County (110.76), Tomaszów Lubelski County (106.17), Krasnystaw County (102.32), and Chełm County (100.64), while the lowest rates were found in Lublin County (2.56) and Ryki County (3.60). The recorded incidence rates in each county in 2019-2020 are shown graphically in Figure 3, and numerically in Table 1.

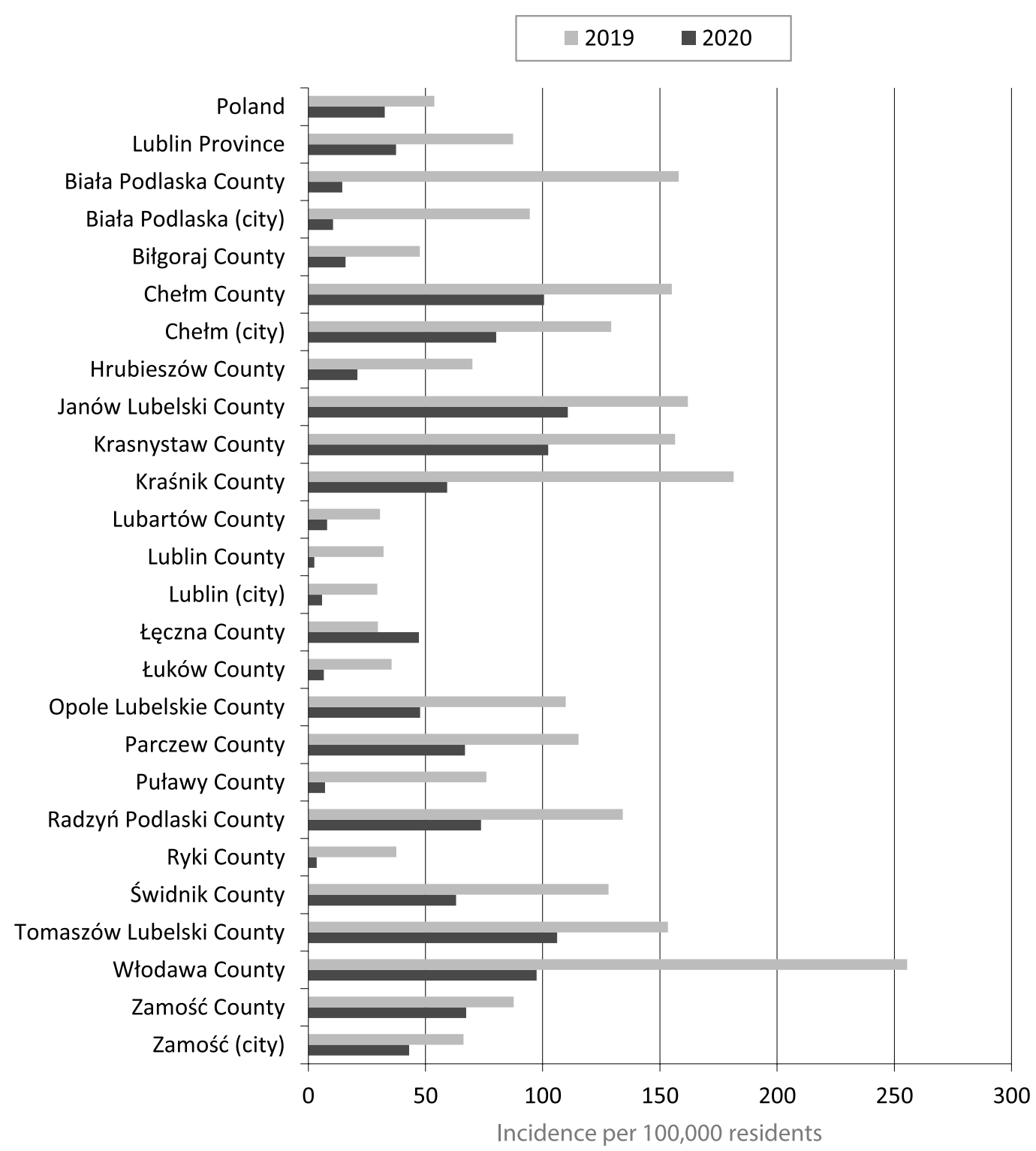

Figure 3. Incidence of Lyme borreliosis in Poland, the Lublin Province and its counties in 2019-2020 (per 100,000 residents) Notes: Own elaboration based on data from the Regional Sanitary and Epidemiological Station in Lublin [9].

Among all the counties of the Lublin Province, an increase in the incidence rate of Lyme borreliosis in 2020 was registered only in Łęczna County. Compared to 2019, the increase was 59\% (from 29.65 to 47.19/100,000 residents). All other counties showed a decrease in the incidence of Lyme borreliosis, similar to the entire Lublin Province and Poland. The biggest numerical decrease of incidence rate was registered in the following counties: Włodawa County (-158.12/100,000), Biała Podlaska County $(-143.43 / 100,000)$, Kraśnik County $(-122.20 / 100,000)$ and the city of Biała Podlaska $(-83.92 / 100,000)$. On the other hand, the largest percentage decrease of this indicator was noted in Lublin County (-92\%), Biała Podlaska County (-91\%), Ryki County (-90\%) and the city of Biała Podlaska (-89\%). Detailed county-by-county data are provided in Table 1. 
Table 1. Number of cases and incidence of Lyme borreliosis in Poland, the Lublin Province and its counties in 2019-2020

\begin{tabular}{|c|c|c|c|c|c|c|}
\hline & \multicolumn{2}{|c|}{ Number of cases } & \multicolumn{3}{|c|}{ Incidence per 100,000} & \multirow{2}{*}{$\begin{array}{c}\text { Difference }^{* *} \\
(\%)\end{array}$} \\
\hline & 2019 & 2020 & 2019 & 2020 & Difference* & \\
\hline POLAND & 20,630 & 12,933 & 53.74 & 32.63 & -21.11 & $-39 \%$ \\
\hline LUBLIN PROVINCE & 1,843 & 784 & 87.42 & 37.42 & -50.00 & $-57 \%$ \\
\hline Biała Podlaska County & 175 & 16 & 157.98 & 14.55 & -143.43 & $-91 \%$ \\
\hline Biała Podlaska (city) & 54 & 6 & 94.46 & 10.54 & -83.92 & $-89 \%$ \\
\hline Biłgoraj County & 48 & 16 & 47.56 & 15.95 & -31.61 & $-66 \%$ \\
\hline Chełm County & 121 & 78 & 155.10 & 100.64 & -54.46 & $-35 \%$ \\
\hline Chełm (city) & 80 & 49 & 129.18 & 80.15 & -49.03 & $-38 \%$ \\
\hline Hrubieszów County & 44 & 13 & 70.01 & 20.96 & -49.05 & $-70 \%$ \\
\hline Janów Lubelski County & 74 & 50 & 161.90 & 110.76 & -51.14 & $-32 \%$ \\
\hline Krasnystaw County & 99 & 64 & 156.50 & 102.32 & -54.18 & $-35 \%$ \\
\hline Kraśnik County & 173 & 56 & 181.44 & 59.24 & -122.20 & $-67 \%$ \\
\hline Lubartów County & 27 & 7 & 30.56 & 7.97 & -22.59 & $-74 \%$ \\
\hline Lublin County & 50 & 4 & 32.14 & 2.56 & -29.58 & $-92 \%$ \\
\hline Lublin (city) & 100 & 20 & 29.43 & 5.91 & -23.52 & $-80 \%$ \\
\hline Łęczna County & 17 & 27 & 29.65 & 47.19 & +17.54 & $+59 \%$ \\
\hline Luków County & 38 & 7 & 35.58 & 6.59 & -28.99 & $-81 \%$ \\
\hline Opole Lubelskie County & 65 & 28 & 109.78 & 47.70 & -62.08 & $-57 \%$ \\
\hline Parczew County & 40 & 23 & 115.24 & 66.92 & -48.32 & $-42 \%$ \\
\hline Puławy County & 86 & 8 & 75.99 & 7.12 & -68.87 & $-91 \%$ \\
\hline $\begin{array}{l}\text { Radzyń Podlaski } \\
\text { County }\end{array}$ & 79 & 43 & 134.22 & 73.76 & -60.46 & $-45 \%$ \\
\hline Ryki County & 21 & 2 & 37.51 & 3.60 & -33.91 & $-90 \%$ \\
\hline Świdnik County & 92 & 45 & 128.06 & 63.00 & -65.06 & $-51 \%$ \\
\hline $\begin{array}{l}\text { Tomaszów Lubelski } \\
\text { County }\end{array}$ & 127 & 87 & 153.45 & 106.17 & -47.28 & $-31 \%$ \\
\hline Włodawa County & 98 & 37 & 255.52 & 97.40 & -158.12 & $-62 \%$ \\
\hline Zamość County & 93 & 71 & 87.64 & 67.39 & -20.25 & $-23 \%$ \\
\hline Zamość (city) & 42 & 27 & 66.21 & 43.00 & -23.21 & $-35 \%$ \\
\hline
\end{tabular}

Notes:

* - the difference in the value of the incidence rate between 2019 and 2020;

** - difference in the value of the incidence rate between 2019 and 2020 in percent.

Own elaboration based on data from the Regional Sanitary and Epidemiological Station in Lublin [9].

\section{Discussion}

The global COVID-19 pandemic has dominated the attention of healthcare professionals, affecting all areas of care. Due to concerns about the spread of COVID-19, patient visits have been reduced in favor of telemedicine consultations that preclude a complete physical examination. At the same time, the variety of symptoms associated with COVID-19 has resulted in many patients with other conditions not being diagnosed at all or not being diagnosed in a timely manner [11].

The spring 2020 COVID-19 pandemic in the northern hemisphere coincided with the seasonal onset of tick exposure. The decreases in the number of reported cases of Lyme borreliosis observed in Poland in 2020 are so significant that it is difficult not to associate them with the pandemic. In Poland, the organization of the health care system changed with the advent of the COVID-19 pandemic. The prevailing epidemiological situation forced the conversion of infectious disease wards into COVID-19-only wards [12], which undoubtedly affected the difficulty of accessing medical care for patients with ailments other than those resulting from SARS-CoV-2 infection, especially for other infectious diseases, including Lyme borreliosis. Alarming data were published by the staff of the Department of Infectious Diseases and Neuroinfection of the Medical University of Bialystok, Poland, which has been diagnosing and treating patients with tick-borne diseases for years. The number of firsttime visits of patients with Lyme borreliosis at the clinic's Anthropozoonosis Outpatient Department was 290 in 2019 and only 45 in 2020 (an 84.5\% decrease) [12]. 
Moniuszko-Malinowska et al. analyzed potential reasons for the decline in reported cases of tick-borne diseases, including Lyme borreliosis. Among the most common were:

- difficulty in accessing medical care for patients with conditions other than those resulting from SARSCoV-2 infection,

- need to test for SARS-CoV-2 infection before hospitalization,

- fear of SARS-CoV-2 infection during diagnosis and treatment of other diseases,

- hospitalizations on wards that have difficult access to diagnosis of Lyme borreliosis and other tick-borne diseases,

- incomplete reporting due to increased strain on the health care system,

- lockdown affecting the reduction of exposure to tick bites [12] (among the many restrictions in place due to the COVID-19 pandemic, a ban on leaving home was enacted in early spring 2020, leaving only minor exceptions relating to leaving to commute to work or to take care of necessary daily needs; for a short period of time, there was also a ban on the use of public and vegetation-covered green areas and public forest areas) [13-16].

Moniuszko-Malinowska et al. pointed out that with the emergence of COVID-19, other diseases, including infectious diseases, have not disappeared and should still be diagnosed and treated as soon as possible to prevent distant post-disease complications [12]. Misdiagnosis and delay in diagnosis of Lyme borreliosis can lead to spread of the spirochetes and involvement of distant systems and organs, primarily the nervous system, musculoskeletal system, and heart [17]. Wormser et al. described the cases of three US patients who had a delayed diagnosis of tick-borne disease as a result of difficulties in accessing diagnostics in the COVID-19 era [11]. Novak et al. described the case of a 67-year-old man whose COVID-19 pandemic-induced delayed diagnosis of Lyme borreliosis resulted in disseminated infection and paralysis of the sixth nerve [18].

The large decrease in the number of registered cases of Lyme borreliosis observed in 2020 in the Lublin Province is undoubtedly related to the occurrence of the pandemic and difficulties in access to medical care for patients with ailments other than those resulting from the SARS-CoV-2 infection. In 2020, more than 67 thousand cases of SARS-CoV-2 virus were registered in the Lublin Province (incidence: 3,212/100,000 residents). The highest incidence of COVID-19 was reported in the fourth quarter of $2020(64,919$ cases, accounting for $95.9 \%$ of all reported cases), mainly in November: 32,445 (47.9\% of all reported cases) [10]. At the same time, the fourth quarter of 2020 saw the largest decrease in Lyme borreliosis cases, over 5 -fold, compared to the previous year [8]. Of the 67,748 cases of SARS-CoV-2 infection registered in 2020,12,256 people were hospitalized, accounting for $18.09 \%$ of all patients, but in the first half of the year, due to the small number of infected people and the lack of experience in treating the disease, almost all detected cases (from 67\% in June to $94.7 \%$ in March), including asymptomatic people, were hospitalized. In the second half of the year, symptomatic patients and/or those with comorbidities who were at risk for severe disease were admitted to the hospital [10]. According to preliminary data from the National Institute of Public Health - National Research Institute (as of 22 ${ }^{\text {nd }}$ July 2021), in 2020, in addition to a marked decrease in the number of cases of Lyme borreliosis, a marked decrease in hospitalizations due to this disease was also noted (in the Lublin Province from 15.1\% in 2019 to 5.2\% in 2020, and overall in Poland from $8.2 \%$ to $3.5 \%$ ) [8].

A decrease in the number of registered cases of Lyme borreliosis in 2020 in the Lublin Province by more than 1,000 cases compared to the previous year may in many cases be due to a delayed diagnosis in the early form of the disease due to the COVID-19 pandemic. This should alert local physicians to the possibility of more patients presenting with late manifestations of Lyme borreliosis than ever before. These patients require the earliest possible diagnosis and appropriate treatment to prevent distant post-disease complications. This particularly concerns the residents of Włodawa County, Biała Podlaska County, Kraśnik County and Biała Podlaska city.

\section{Conclusions}

Significant decreases in the incidence of Lyme borreliosis observed in 2020 in the Lublin Province are undoubtedly related to the COVID-19 pandemic and difficulties in accessing medical care for patients with ailments other than those resulting from SARS-CoV-2 infection. Local healthcare providers should be alert to the possibility that more patients than ever before are presenting with a diagnosis of Lyme borreliosis delayed by the COVID-19 pandemic and, therefore, late manifestations of the disease.

\section{Disclosures and acknowledgements}

The author declares no potential conflicts of interest with respect to the research, authorship, and/or publication of this article. This work was funded by the author. 


\section{References:}

1. Adeolu M, Gupta RS. A phylogenomic and molecular marker based proposal for the division of the genus Borrelia into two genera: the emended genus Borrelia containing only the members of the relapsing fever Borrelia, and the genus Borreliella gen. nov. containing the members of the Lyme disease Borrelia (Borrelia burgdorferi sensu lato complex). Antonie van Leeuwenhoek. 2014; 105: 1049-1072. https://doi.org/10.1007/ s10482-014-0164-x

2. Barbour AG, Adeolu M, Gupta RS. Division of the genus Borrelia into two genera (corresponding to Lyme disease and relapsing fever groups) reflects their genetic and phenotypic distinctiveness and will lead to a better understanding of these two groups of microbes (Margos et al. (2016) There is inadequate evidence to support the division of the genus Borrelia. Int. J. Syst. Evol. Microbiol. doi: 10.1099/ijsem.0.001717). International Journal of Systematic and Evolutionary Microbiology. 2017; 67(6). https://doi.org/10.1099/ ijsem.0.001815

3. Pancewicz SA, Garlicki AM, Moniuszko-Malinowska A, Zajkowska J, Kondrusik M, Grygorczuk S, et al. Diagnosis and treatment of tick-borne diseases. Recommendations of the Polish Society of Epidemiology and Infectious Diseases. Przegl Epidemiol. 2015, 69(2): 309-316.

4. Stanek G, Strle F. Lyme borreliosis - from tick bite to diagnosis and treatment. FEMS Microbiology Reviews. 2018; 42(3): 233-258. https://doi.org/10.1093/femsre/fux047

5. Zbrzeźniak J, Paradowska-Stankiewicz I. Lyme disease in Poland in 2017. Przegl Epidemiol. 2019; 73(3): 317320. https://doi.org/10.32394/pe.73.37

6. Stefanoff P, Rosińska M, Zieliński A. Epidemiology of tick-borne diseases in Poland. Przegl Epidemiol. 2006; 60: 151-159.

7. The National Institute of Public Health - National Research Institute. [Definitions of infectious diseases cases for the purpose of the epidemiological surveillance]. Warsaw: The National Institute of Public Health - National Research Institute; 2007 (in Polish).

8. www.pzh.gov.pl [Internet]. Warsaw: The National Institute of Public Health - National Research Institute [cited 2021 Aug 16]. Available from: https://www.pzh.gov.pl/ (in Polish).

9. www.gov.pl/web/wsse-lublin [Internet]. Lublin: Regional Sanitary-Epidemiological Station in Lublin [cited 2021 Aug 6]. Available from: https://www.gov.pl/web/wsse-lublin (in Polish).

10. www.gov.pl/web/wsse-lublin [Internet]. Lublin: Regional Sanitary-Epidemiological Station in Lublin; 2021. [Assessment of the sanitary safety in the Lublin Province in 2020] [cited 2021 Aug 16]. Available from: https://www.gov.pl/web/wsse-lublin (in Polish).

11. Wormser GP, Jacobson E, Shanker EM. Negative impact of the COVID-19 pandemic on the timely diagnosis of tick-borne infections. Diagn Microbiol Infect Dis. 2021; 99(1): 115226. https://doi.org/10.1016/j. diagmicrobio.2020.115226

12. Moniuszko-Malinowska A, Pancewicz S, Czupryna P. Has COVID-19 influenced on tick-borne diseases epidemiology?. Przegl Epidemiol. 2020; 74(4): 740-741. https://doi.org/10.32394/pe.74.65

13. [Regulation of the Minister of Health of $24^{\text {th }}$ March 2020 amending the Regulation regarding the announcement of the epidemic state in Poland (Journal of laws 2020, item 522)] (in Polish).

14. [Regulation of the Council of Ministers of $31^{\text {st }}$ March 2020 on the establishment of certain restrictions, orders and prohibitions in connection with the occurrence of a state of epidemic (Journal of laws 2020, item 566, 577, 624)] (in Polish).

15. [Regulation of the Council of Ministers of $10^{\text {th }}$ April 2020 on the establishment of certain restrictions, orders and prohibitions in connection with the occurrence of a state of epidemic (Journal of laws 2020, item 658, 673, 674)] (in Polish).

16. Włodarczyk WC. [Remarks on COVID-19 pandemic in Poland. A health policy perspective]. Zdrowie Publiczne i Zarządzanie. 2020; 18(2): 126-148 (in Polish). https://doi.org/10.4467/208426270Z.20.013.12766

17. Steere AC, Strle F, Wormser GP, Hu LT, Branda JA, Hovius JWR, et al. Lyme borreliosis. Nature Reviews Disease Primers. 2016; 2(1): 16090. https://doi.org/10.1038/nrdp.2016.90

18. Novak CB, Scheeler VM, Aucott JN. Lyme disease in the era of COVID-19: a delayed diagnosis and risk for complications. Case Rep Infect Dis. 2021; 13(2021): 6699536. https://doi.org/10.1155/2021/6699536 